\title{
Physiotherapy Comprehensive Care as an Integrated Care
}

\author{
Sri Sunaringsih Ika Wardojo and Rakhmad Rosadi* \\ Department of Physiotherapy, Faculty of Health Science, University of Muhammadiyah Malang, \\ Indonesia \\ Jl. Bendungan Sutami 188A, Kota Malang, Jawa Timur, 65145 \\ *Corresponding author: rakhmad21@gmail.com
}

\begin{abstract}
Background: People's cost limitation in accessing health service, especially for degenerative diseases that need relatively long term health care has caused the increase of cases that need physiotherapy service. Objective: This research is aiming at identifying people's diseases problems that need physiotherapy and assets needed in physiotherapy service, selecting problem issues by thorough analyzing the characteristics of physiotherapy problems, defining the need of physiotherapy service by using measured terminology including economic and social factors, formulating the design of physiotherapy service model (service inside and outside building). Method: This research used observational method. Result: it indicates that some health problems namely post stroke rehabilitation as well as palliative cases needs physiotherapy service. Conclusion: Physiotherapy service model can be developped through integrative system with post-discharge planning patient in UMM hospital.
\end{abstract}

Key words: physiotherapy, disease, economic, social factors

\section{INTRODUCTION}

Physiotherapy service is one of health services, that is continually and comprehensively applied on individual and family in their homes to increase, maintain or recover health or maximize independency level and minimize the impact of disease. The increase of chronic disease mostly undergone by elderly people who need continuous and longtime care and it is suitable if the chosen care service is physiotherapy based - care (Markkanen, 2008; Lang, Edwards, \& Fleiszer, 2008). Furthermore, we should take into account that doing physiotherapy care is by making service access between provider agency and patient closer.

People's cost limitation in accessing health service, especially for degenerative diseases that need relatively long medical care has caused the increase of cases that need physiotherapy (DEPKES RI, 2006). For example, post stroke-patient that experiences paralysis complication and needs relatively long time-rehabilitation service. Profit oriented hospital management views that too long client service (more than one week) is detrimental even burdening to the management. Many people feel that having nursed in health service institution is similar to limiting human's life because one cannot enjoy life optimally since they have to stick to the rules. Several clients feel home environment is more comfortable than physiotherapy in the hospital so that can precipitate recovery process. In Lang's view (2011), home care that should be paid attention to is reducing environmental risks.

The previous research results were: 1) there is close correlation of perception to inside UMM people's interest of physiotherapy service (Prasetyo, Kumboyono, Wardani, 2012), 2) 
there is close correlation of perception to external UMM people's interest to physiotherapy service model hospital (Prasetyo, Kumboyono, Wardani, 2012), 3). The need of physiotherapy service developing cooperated with partner hospital (Prasetyo, Kumboyono, Wardani, 2012), 4) The need of executor nurse skill development in giving physiotherapy service so that it gives impact to patient's satisfaction (Wardojo, Ruhyanudin, Prasetyo, 2014). Therefore, this research is aiming at developing physiotherapy service system cooperated with hospital as a strategy to make care physiotherapy service is more accessible and longer time for people and it is hoped can increase the degree and independency of community health.

\section{METHOD}

This research used observational method design. The population in identification research of health problems of people who need physiotherapy service were medical record documents of patient who were nursed in UMM hospital along September 2013 - September 2015. This research used patient's medical record as the sample. This research also used total sampling. Assets that were needed in identification research were medical and paramedical officers in UMM hospital. For this case, the research used accidental sampling. Population in selecting physiotherapy problem issues were medical and paramedical officers as well as people surround UMM hospital. For this sake, the research also used accidental sampling. Population in defining economic and social based-physiotherapy service were people surround UMM hospital and patients who were nursed in UMM hospital. For this sake, the research also used accidental sampling. Populations in model of physiotherapy service design were various primary literatures. This research was conducted in UMM hospital.

\section{RESULT AND DISCUSSION}

Based on the study result of medical record in UMM hospital that has been conducted along March 2014-October 2015, it was found some following potential cases that need physiotherapy service (table 1).

Table 1 Potential cases that need home care in UMM hospital in 2015

\begin{tabular}{lcc}
\hline No & \multicolumn{1}{c}{ Case Type } & Percentage \\
\hline 1. & Post stroke-rehabilitation & $55 \%$ \\
2. & Palliative case & $45 \%$ \\
\hline & TOTAL & $\mathbf{1 0 0 \%}$ \\
\hline
\end{tabular}

The data above show that post stroke rehabilitation is the most prioritized case which need physiotherapy service since it reached the highest percentage 55\% based on the result of medical record. Subsequently, palliative cases need physiotherapy services for $45 \%$.

The data above show that home health care is one of long-term care types given by trained professional and non-professional workers (Helwiah, 2006). Home health care as the one of health service types is a range of continuing and comprehensive health service given to individual and family in their homes that is aiming at increasing, maintaining or recovering health as well as maximizing independence level and minimizing the impact of disease including terminal disease. Organized servicer plans, coordinates, and provides the appropriate service to individual and family patients to give physiotherapy through staff or system based on agreement of combination of both (Warhola, 1980 in Helwiah, 2006).

Sherwen (1991 in Helwiah, 2006) and Parson, et al (2011) define home health care as the internal part of physiotherapy service done by nurses to help individual, family and 
society to reach independence in solving health problems they face. Stuart (1998 in Helwiah, 2006) explains that home health care as the part of physiotherapy process in hospital and the continuation of discharge planning for clients that should go home. Home health care is usually done by nurse form early hospital, nurse of community in which the client exists, or special team to conduct home health care. According to American of Nurses Association (1992 in Helwiah, 2006) home health care is the combination of people's health care and technical ability chosen from community and clinical health services.

Beside disease, cases displayed on table 2, people around UMM hospital also experience morbidity condition or pain rate of many acute and chronic diseases. We can also see this case from the list of top 10 diseases handled in UMM hospital.

Table 2 The List of Top Ten Diseases in UMM Hospital in 2015

\begin{tabular}{lccccc}
\hline \multicolumn{1}{c}{ Disease Type } & \multicolumn{5}{c}{ In 2015 } \\
\hline Dengue hemmorhagic & May & June & July & August & September \\
Thypoid fever & 2 & 2 & 2 & 2 & 10 \\
Fever unspecified & 3 & 1 & 3 & 3 & 1 \\
Nausea and vomiting & 4 & 5 & 5 & 5 & 9 \\
Dengue fever & 5 & 8 & 6 & 6 & 7 \\
Grastritis & 6 & 4 & 4 & 4 & 8 \\
Stroke & 7 & 7 & 7 & 7 & 5 \\
New born diseases & 8 & 6 & 8 & 8 & 6 \\
Acute gastritis & 9 & 9 & 10 & 9 & 2 \\
Supervision of high risk & 10 & 10 & 9 & 10 & 3 \\
\hline
\end{tabular}

Table 2 explains that acute diseases cause the rate of people's pains, the most of them is hemorrhagic, and the most of chronic disease is stroke. The pain rate is the indicator used to know certain disease case of people that can be obtainned through two indicators: prevalence and incidence rates (Zlotnick, 2006). The prevalence rate explains the number of disease cases (old and new cases) of certain time per 1000 populations (Dodd 2006). This indicator can describe the recent health condition. The incidence number refers to the number of new disease cases of certain time per 1000 populations. The incidence disease is beneficial in evaluating a program conducted to overcome certain disease (Shi, 2007; Dodd, 2006).

Beside pain rate, mortality rate is aiming at describing the number of mortality cases in certain society that can be obtainned by counting such indicators as Crude Birth Rate, Age Specific Date Rate (ASDR), Life Expectancy, Maternal Mortality Rate, Infant Mortality (Bleumink, 2006).

Based on the results of discussions with some medical workers, some physiotherapy problems should be prioritized to solve. First, the lack of coordination among hospital management, medical workers and paramedics in communicating post discharge planning patients who remain needs home health care helped by the related medical workers so there are many post discharge planning patients inside and outside UMM hospital who have not been optimally treated.

There is no procedure in UMM hospital which regulate integrally home health care service for post discharge planning patients and outside UMM hospital patients who need physiotherapy service. Physiotherapy industry management consists of three points: service manager, service implementation and client. Service manager is an agent or unit that is responsible of all home health care services in providing medical workers, facilities, tools and service mechanism based on set standard. Service executors consist of professional physiotherapy workers accompanied by other professional and non-professional workers. Service implementation consists of case coordinator and service implementation. This involves physiotherapy lecturer as case manager accompanied by physiotherapist graduated 
from UMM or physiotherapist in hospitals and clinics outside UMM. Clients are ones who get home health care that involves one of family members as the caretaker as the representative of the client.

Identification of economic and social based-physiotherapy service means that giving physiotherapy service needs market analysis related to economy potential of people around UMM hospital. Hospitalization room used by clients can indicate economy potential.

Table 3 The Insurers of Service Cost in UMM Hospital in 2015

\begin{tabular}{lccccccc}
\hline \multirow{2}{*}{ Insurer } & \multicolumn{7}{c}{ In 2015 } \\
\cline { 2 - 7 } & March & April & May & June & July & August & September \\
\hline General & $391 / 75 \%$ & $413 / 81 \%$ & $321 / 67 \%$ & $169 / 70 \%$ & $206 / 87 \%$ & $271 / 80 \%$ & $274 / 77 \%$ \\
BPJS & $129 / 25 \%$ & $85 / 17 \%$ & $148 / 31 \%$ & $72 / 30 \%$ & $25 / 11 \%$ & $59 / 18 \%$ & $80 / 23 \%$ \\
Insurance & 0 & $10 / 2 \%$ & $8 / 2 \%$ & 0 & $5 / 2 \%$ & $7 / 2 \%$ & 0 \\
Total & 520 & 508 & 477 & 241 & 236 & 337 & 354 \\
\hline
\end{tabular}

In table 3, the largest community as the insurer is general. It means that clients themselves and family pay service cost without using BPJS and other insurances. In table 4, we can see that most people chose class 1 room as their physiotherapy place. This case shows that economically and socially, the customers of UMM hospital is in well economic level.

Table 4 Physiotherapy Service Place in UMM Hospital

\begin{tabular}{lccccccc}
\hline Hospitalization & \multicolumn{7}{c}{ In 2015 } \\
\cline { 2 - 7 } Room & March & April & May & June & July & August & September \\
\hline Class III & $184 / 35$ & $156 / 30 \%$ & $145 / 30 \%$ & $33 / 14 \%$ & $54 / 23 \%$ & $80 / 24 \%$ & $88 / 25 \%$ \\
Class II & $91 / 17,5 \%$ & $95 / 19 \%$ & $133 / 28 \%$ & $56 / 23 \%$ & $54 / 23 \%$ & $61 / 18 \%$ & $70 / 20 \%$ \\
Class I & $173 / 33 \%$ & $205 / 40 \%$ & $153 / 32 \%$ & $146 / 61 \%$ & $113 / 48 \%$ & $186 / 55 \%$ & $188 / 53 \%$ \\
VIP & $72 / 14 \%$ & $52 / 10 \%$ & $46 / 10 \%$ & $6 / 2 \%$ & $15 / 6 \%$ & $10 / 3 \%$ & $8 / 2 \%$ \\
Total & 520 & 508 & 477 & 241 & 236 & 337 & 354 \\
\hline
\end{tabular}

Physiotherapy as a service product urgently needs to analyze market potential to the service consumers. Consumer market analysis is important to determine market segment in which physiotherapy business can exist. Market segment determination includes determination of physiotherapy service users' characteristics. Opel, et al (2009) says that from social market strategy, we can get social issues in public service sector (such as: service place, service price, offered product, intended health promotion, and subsequently, it gives positive impact to the product that will be offered to the society.

The social issues in public sector obtained by physiotherapy business manager are classified into main approaches: traditional and contemporary approaches. Traditional approach is classified into micro economy model and macro economy model. Micro economy model more describes what consumers buy and the number of what they will buy (Shi, 2007; Dodd, 2006). Macro economy view concerns on aggregate stream in economic. In economical perspective, we can see the economical condition correlation pattern in below picture. From the picture, we know that consumer's feeling is the result of influence modification of economical conditions as the consumers' trust level about economical condition they face and their wish of the future economical condition. Contemporary approach more focuses on decision process that involves consumers in considering the chosen product and service. This approach also largely develops material of behavior science (Shi, 2007; Dodd, 2006).

There are many factors that influence consumer's purchase decision that is also called behavior factors. Consumer's purchase is strongly influences by cultural, social, personal and psychological characteristics. Cultural characteristics that include culture sub-culture and social class have largely influence consumer's behavior and interest. Culture is the most 
cause of one's behavior and interest (Shi, 2007; Dodd, 2006). Sub-culture create crucial market segment as the basis of product design based on their needs. Social class will show product and certain brand choices in every field. Social factors consist of small group, family, rules and consumer social status. Group functions as the direct or indirect reference that creates one's attitude and behavior. Family members influence significantly to buyers' behavior. Role and status will correlate each other when people purchase something, in which every role brings status as the representative of people's reward. Therefore, someone might choose product that represents his/her status in the (Shi, 2007; Dodd, 2006).

Such personal characteristic as age, life cycle stage, job, economical conditions, life style, personality and self- concept might influence the buyer's decision. Someone's choices in buying something are also influenced by other four the most important psychological factors: motivation, perception, knowledge, faith and attitude. Motivation is an encouragement to seek satisfaction of needs mencari (Markkanen, 2008; Lang, Edwards, \& Fleiszer, 2008). Perception is a process in which someone chooses, organizes, and interprets information to create valuable description of world. Knowledge is the results of learning that describes individual's behavior changes due to experiences. Through learning, people are able to get faith and attitude. Faith describes something and attitude places the way of thinking of likeness and (Markkanen, 2008; Lang, Edwards, \& Fleiszer, 2008).

Based on the correlation pattern between the highest and the lowest effort types, the consumer decision-making level is categorized into three points: extensive problem solving, limited problem solving and routinized response behavior. For extensive problem solving level, consumers need more information to make sure the decision. For limited problem solving level, the consumers do not too much need information, however, they remain seek information to affirm their faith. For routinized response behavior level, since the consumers have had many self-purchase experiences, perhaps they do not need any information (Shi, 2007; Dodd, 2006).

Consumer decision-making process consists of five stages like what have been stated in picture below; they are: need introduction, information search, alternative evaluation, purchasing decision, and post purchasing behavior. Need introduction stage is the first stage of consumers' decision-making process in which they recognize certain problem or need (Markkanen, 2008; Lang, Edwards, \& Fleiszer, 2008; 2011). Consumers find the differences between the real conditions and the intended ones. Internal and external stimulus might trigger needs. Consumers' decision-making process second stage is information search in which they are more interest in seeking more information. Consumers might increase their attention or perhaps they actively search information. The available information is in such sources as personal, commercial, public and experience sources (Shi, 2007; Dodd, 2006).

\section{CONCLUSION}

Based on the results of identification, the health problems that mostly need physiotherapy service are post stroke rehabilitation cases that was $48 \%$ of total cases, while the other health cases were related to post stroke-rehabilitation care as well as physiotherapy on palliative cases. Assets that are remain needed to facilitate physiotherapy service integrated with UMM hospital are the availability of manual therapy tools, diathermy, compatible $\mathrm{O}_{2}$ tube, patient's compatible bed, electrical tension meter. Besides, physiotherapy issues in UMM hospital that still exist, for example, the lack of coordination between management and medical workers in giving physiotherapy service to post discharge planning patient (UMM hospital) or referral patient from outside UMM hospital, and there is no procedure in UMM hospital that integrally organize home health care service. 


\section{REFERENCES}

Bleumink. (2006). 'Quantifying the heart failure epidemic: Prevalence incidence rate, lifetime risks, and prognosis of heart failure: the Rotterdam study", Europe Heart Journal, vol. 25, no.18, (online Scopus).

DEPKES RI. (2006). Panduan pelayanan keperawatan kesehatan di rumah. Direktorat Bina Pelayanan Keperawatan. Direktorat Jenderal Bina Pelayanan Medik. Jakarta

Dodd, RY. (2006). Current prevalence and incidence of infectious disease markers and estimated window-period risk in the American Red Cross blood donor population', Transfusion Journal, vol 42, no. 8, (online Wiley).

Helwiah, R. (2006). Fisioterapi sebagai bentuk praktek mandiri perawat di rumah. Bandung: Jurnal Keperawatan Universitas Padjadjaran, Vol. 5 No. IX

Lebrun-Harris, LA. (2013). Health status and health care experiences among homeless patients in federally supported health centres: findings from the 2009 patients surveys", Journal of Health Services Research, vol. 48, no.3, (online PubMed).

Lang, A, Edwards, N, \& Fleiszer, A. (2008). Safety in fisioterapi: a broadened perspective of patient safety School of Physiotherapy, University of Ottawa, Ottawa, Canada. International Journal for Quality in Health Care, Volume 20, Number 2: pp. 130-135

Lang, A. (2011). There's no place like home: research, practice and policy perspectives regarding safety in fisioterapi. International Journal for Quality in Health Care Volume 22, Number 2: pp. 75-77

Markkanen, P. (2008). Studying home health care nurses and aides: research design and challenges. Journal of Research In Physiotherapy. Vol 13 (6) 480 - 495

Opel, DJ, Diekema, DS, Lee, NR, \& Marcuse, EK. (2009). Social Marketing as a Strategy to Increase Immunization Rates. Arch Pediatri Adolesc Med, Vol 163, No. 5.

Parson, J, Rouse, P, Robinson, EM, Sheridan, N, \& Connolly, MJ. (2011). Goal setting as a feature of fisioterapi services for older people: does it make difference?. Journal Age and Ageing , 41:24-29

Prasetyo, YB, Djauhari, T, Kumboyon, Rosadi, R, Kurnia. (2012). Matahari fisioterapi sebagai terobosan bisnis di Fakultas Ilmu Kesehatan Universitas Muhammadiyah Malang. Jurnal Dedikasi Vol 9 Mei 2012 ISSN 1693-3214

Prasetyo, YB, Kumboyono, Wardani, NS. (2012). Perceptions and enthusiasm community: empowering strategy information technology based marketing in fisioterapi services. The Fourth International Physiotherapy Conference: Working Together For Health Security, Thailand

Shi, L. (2007). Community health centres and racial/ethnic disparities in healthy life', International Journal of Health Services, vol. 31, no. 3, (online PubMed).

Wardojo, SSI, Ruhyanuddin, F \& Prasetyo, YB. (2014). Prosiding: Tantangan Profesi Kesehatan Pada Masa Akan Datang. ISBN 978-979-796-284-5. Fakultas Ilmu Kesehatan Universitas Muhammadiyah Malang.

Zlotnick, C. (2006), "Survey findings on characteristics and health status of clients treated by the federally funded (US) Health Care for the homeless program", Journal of Health Social Care Community, vol. 1, no. 17, (online PubMed). 